"Sustained Monopolistic Relationships: an interdisciplinary case" British Journal of Management Vol. 14 No.4 (2003) pp.323-338

\title{
Sustained Monopolistic Business Relationships: An Interdisciplinarity Case
}

\author{
Authors: \\ Andrew Humphries \\ UK Defence Logistics Organisation \\ Dr Richard Wilding \\ Cranfield Centre for Logistics and Supply Chain \\ Management, Cranfield University \\ Web: www.richardwilding.info
}




\title{
Sustained Monopolistic Business Relationships: An Interdisciplinarity Case
}

\begin{abstract}
$\underline{\text { Abstract }}$
Business-to-business relationships within sustained monopolies, such as those within UK Defence Procurement, have received scant attention by Management Researchers. This is unusual because under these market circumstances there appear to be few incentives to achieve mutually beneficial outcomes despite their strategic policy importance. This paper argues that an understanding of the monopolistic environment using a Transaction Cost Economics theoretical framework and Supply Chain Management, Relationship Marketing and Transaction Cost Economics concepts provides an innovative, interdisciplinarity approach to solving this problem as well as testing aspects of these disciplines empirically in a novel area. This paper describes the results from a substantial research project to test this hypothesis in the UK Defence Procurement situation. It reveals a number of key dynamics within the sustained monopolistic relationships surveyed and suggests considerable potential for further research.
\end{abstract}

Keywords: Interdisciplinarity, Supply Chain Management, Relationship Marketing, Transaction Cost Economics, monopoly, Defence Procurement

\section{Introduction}

This paper addresses an under-researched area of business-to-business relationships, namely the relationship which exists where one or both parties has a monopoly of supply or demand (Fishwick, 1993). Many theories of buyer-seller relationships have discussed in general terms the concept of structural bonds and opportunism, but not adequately applied them to the extreme situation of monopoly buyer and monopoly seller relationships. We first summarise the difficulties faced by the UK Ministry of Defence (MoD) and its major industrial suppliers in moving away from traditional, adversarial relationships whilst facing increasingly monopolistic business dealings. We then justify the use of a Transaction Cost Economics (TCE) model as a theoretical lens through which to view the problem. Interdisciplinarity is a radically different approach that combines two or more disciplines to produce an outcome that is more than the sum of the parts (Starkey \& Madan, 2001). Because the nature of the business is Supply Chain Management (SCM), Relationship Marketing (RM) provides an effective framework for describing business-to-business relationships and, TCE describes the contractual arrangements of procurement, this paper argues that concepts from these fields can be used to address the problems identified when viewed through the TCE theoretical lens. The authors describe an exploratory research programme within the Sea, Land and Air elements of the UK Defence Procurement (DP) environment and present findings which not only expand our knowledge of the business area in question but also provide a better understanding of the relational dynamics of sustained monopolies.

\section{UK Defence Procurement}

Historically, the relationship between the UK MoD and the UK Defence Industries has been adversarial. On one hand, with estimated equipment procurement expenditure of $£ 10,162$ million in 2000/01 (DASA, 2001), the 
UK MoD has immense power as British industry's largest single customer. It can thus determine the 'size, structure, conduct, ownership and performance of the industry through pricing, profitability, technical progress and exports' (Hartley 1998). On the other hand, industry is a major exporter and contributor to the UK's balance of payments, its production for foreign sales reduces UK MoD's equipment unit costs, it develops strategically important technologies such as aero engines and is a significant employer in UK industrial areas. However, the major UK Defence companies are virtual domestic monopolies and can team with foreign companies to reduce the choice of supplier. The UK MoD/industrial supplier relationship is thus dominated by a monopoly market in which each side wields considerable power but where lack of trust and the option to leave often reduces efficiency, increases costs and offers little incentive to co-operate (Humphries \& Wilding, 2001c, Palmer, 2001, Parker \& Hartley 1997). Against this background, the UK Government stated that its Smart Acquisition initiative depended heavily on partnership in order to reap the benefits of competition and collaboration ( $\mathrm{Cm} 4446,1999)$. It is this challenging and potentially mutually exclusive business objective that drives a need for research in this area.

\section{The Monopoly Environment}

In our search of the literature for a suitable model with which to examine the relationship conditions within a monopoly, we first considered 2 relationship power perspectives. Michael Porter's (1980) five forces model of competitive advantage considers business relationships are characterised by a short-term orientation, armslength competition and the exercise of market power (Rugman \& D'Cruz, 2000). However, although participants may aim to achieve market dominance by limiting competition through the creation of barriers to entry, this does not accurately represent UK DP monopolies where equally powerful 'partners' can be locked in a relationship from which neither can escape. Alternative by Andrew Cox (2000) see the combination of resource utility and scarcity creating a power regime in which the involved parties will employ adversarial/nonadversarial and arms-length/collaborative arrangements depending on their relative power positions as shown in the matrix at Figure 1. 
Way of Working

Arms-Length Collaborative

\begin{tabular}{|c|l|l|}
\cline { 2 - 3 } \multicolumn{1}{c|}{$\begin{array}{c}\text { Inequality } \\
\begin{array}{c}\text { Relative Share } \\
\text { of Value } \\
\text { Appropriation }\end{array}\end{array}$} & $\begin{array}{c}\text { III } \\
\text { Adversarial } \\
\text { Arms-Length } \\
\text { Relationship }\end{array}$ & $\begin{array}{c}\text { Adversarial } \\
\text { Collaborative } \\
\text { Relationship }\end{array}$ \\
\cline { 2 - 3 } Equality & II $\begin{array}{c}\text { Non- } \\
\text { Adversarial } \\
\text { Arms-Length } \\
\text { Relationship }\end{array}$ & $\begin{array}{c}\text { NVon- } \\
\text { Adversarial } \\
\text { Collaborative } \\
\text { Relationship }\end{array}$ \\
\hline
\end{tabular}

Figure 1. Relation Power Analysis (Cox, 2000) Reproduced by kind permission of MCB, Copyright (2002).

Quadrant I suggests limited information, resource sharing and the buyer/supplier aiming to obtain a greater share of the exchange value. In quadrant II a long-term, balanced relationship is sought where there is little sharing of specific assets but both parties gain some strategic benefit. In quadrant III, the parties work closely together and share sensitive information and costly resources. However, the dominant partner intends to take a disproportionate share of the returns. In quadrant IV, both sides enjoy a close, collaborative, equal arrangement, often called a 'partnership'. This approach offers a clear perspective on the appropriate use of power within a business relationship however, in a sustained monopoly, where neither party has choice over the selection of relationship strategy and where equality of power really means equally disempowered, the Relationship Power Analysis matrix does not provide a robust framework for extending thinking on long-term, monopoly relationships.

In a review of the contracting and TCE literatures, we noted that when the cost of managing the risk associated with human factors such as opportunism became too high, the market could break down and force a firm to internalise the business, in effect creating an internal monopoly (Faulkner \& de Rond, 2000). However, TCE generally treats monopoly as a short-term, highly undesirable market aberration that would normally be dealt with by government anti-trust regulation (Williamson, 1996). We have nevertheless adapted Oliver Williamson's (1975) Economic Organisation Failure Framework in Figure 2 to describe the environment that creates and sustains a monopolistic relationship rather as a causal model and, borne in mind that for the majority of major contracts in UK DP, monopoly is considered to be in the public interest (Fishwick, 1993). 


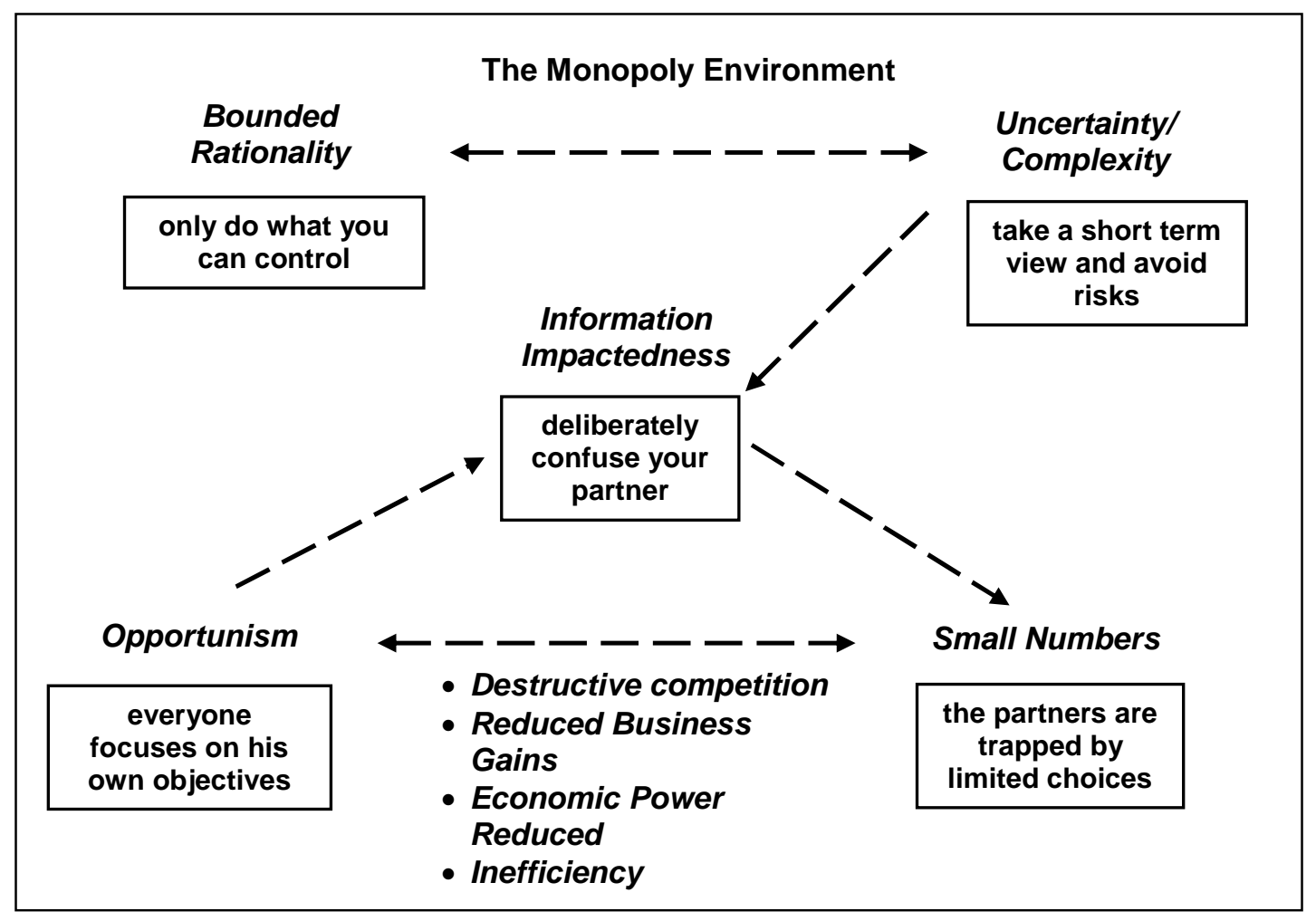

Figure 2. Economic Organisation Failure Framework (Adapted with kind permission of The Free Press, Simon \& Schuster Inc, Copyright (2003), from Williamson (1975)

Although both sides need to rely on maintaining close relationships over the supply of highly specialised goods (Grant, 1995), inevitably they are open to opportunistic behaviour (self-interest seeking with guile (Williamson, 1975)). In 1985 the Levene reforms ended MoD's 'cosy relationship' with industry (Hartley, 1998) and introduced uncertainty and complexity into the market (Humphries \& Wilding, 2000). In seeking to obtain public expenditure value for money the UK MoD attempts to drive down industry's profit to a 'reasonable' level and in turn the contractor attempts to inflate the view of his costs to maximise his rate of return. This deliberate obfuscation is information impactedness (selective information disclosures, and distortions which are difficult or expensive to verify at the time and which undermine the durability of contract arrangements) (Liston-Heyes, 1995). The consequences are that industry loses its incentive to perform better and, the UK MoD reduces the resources available to industry that might have been used to fund important Research and Development. This is bounded rationality where personal capacity to rationalise complexity limits performance to the adequate rather than the optimum (Simon, 1957). The sum effect is an adversarial relationship without the freedom to look to the market for alternatives (Parker \& Hartley, 1997) and the formation of small numbers/monopoly situation. Although the authors can find no empirical research using Williamson's (1975) Framework in similar circumstances, it seems to have face validity in the UK DP situation (Humphries \& Wilding, 2001c). We have therefore decided to use it as the theoretical basis on which to investigate this unusual situation. We now turn to a critical review of the theoretical fields; SCM, RM and TCE to determine the extent to which their business-to- 
business relational concepts can provide a means of understanding the dynamics within sustained monopolistic conditions and especially those found within UK MoD DP.

\section{Relationships within the Supply Chain}

SCM is viewed as an integrative, proactive approach to manage the total flow of a distribution channel to the ultimate customer (Matthyssens \& Van den Bulte, 1994). Increased customer service reliability and reduced inventory (Boddy et al, 2000) aim to lower uncertainty and lower costs (Cooper \& Ellram, 1993, Lamming, 1993, Bechtel \& Jayaram, 1997). SCM depends upon co-operative relationships throughout the Supply Chain in order to achieve benefits for all participants (Stevens, 1989) and this involves closer relationships between members which include trust, commitment and collaboration (Spekman et al, 1998). The literature contains a great deal of holistic advice on how this should be achieved but, in practice it is generally operationalised as the integration of chains of suppliers to better satisfy customers (Christopher, 1997, Peck et al, 2000). Although suppliers recognise the need to integrate with their customers, empirical research on modelling and studying end-to-end Supply Chain relationships is limited (Cooper et al, 1997, Bectel \& Jayaram, 1997). It is also apparent that full SCM implementation is not being achieved for other reasons (Spekman et al, 1998). The importance of long-term partnering relationships to focussing on complex, problem solving (Boddy et al, 2000, Hulme, 1997) is acknowledged. Also is the need to base them on openness, shared risks and rewards that leverage the skills of each partner to achieve competitive performance not achieved by the individual (Lambert

et al, 1996). However, firms are still taking a short-term view which tends them towards adversarial relationships (Braithwaite, 1998) and the development of partnering relationships is being obstructed by poor communications allied to a reluctance to accept attitudinal change (Anscombe \& Kearney, 1994). Nevertheless, the obligational nature of these arrangements to overcome opportunistic temptations is evident (Ellram \& Edis, 1996) as is the importance of achieving good business-to-business relationships through partnering as a foundation for achieving the operational benefits of SCM is clearly identified (Cooper et al, 1997). In conclusion, SCM theory appears to be well known by academia and business but research is limited on practical implementation. Furthermore, this research has concentrated on the Private Sector and sheds no light on monopolistic supply chain relationships of the UK DP type (Humphries \& Wilding, 2001c).

\section{Relationships within Relationship Marketing}

RM aims to establish, develop and maintain successful relational exchanges which involves designing and negotiating strategic partnerships with vendors and technology partners through which the firm deploys its distinctive competencies to serve market opportunities (Webster, 1992). The literature thus covers a very wide 
field and tends to lack consistency and also in some areas, depth (Kakabadse \& Kakabadse, 2000). Research has tended to concentrate on vendor/retailer rather than vendor/end customer relationships (Ganesan, 1994) and this has resulted in limited modelling of complete relationship chains (McDonald et al, 1997, Rousseau et al, 1998). Despite these drawbacks RM provides comprehensive views of the various styles used by firms and individuals when they do business with each other - the social relations that shape and define the nature of synergistic interactions between firms (Madhok, 2000). Organisationally, the complexity of business relationships within networks from Dyadic (Anderson et al, 1994) through Interactionist (Metcalf et al, 1992) to the Marriage Analogy (Dwyer et al, 1987, Tuten \& Urben, 2001) and Key Account Management (McDonald et al, 1997) as firms seek closer dealings with a partners to secure reduced uncertainty, managed dependence, exchange efficiency and social satisfaction (Gundlach \& Murphy, 1993, Gummesson, 1999) is clearly and usefully explained. There is also an extensive literature on important behavioural variables which provide valuable guidance on improving business relationships (Evans \& Berman, 2001). These include trust (Goleman, 1998, Kramer, 1999), commitment (Moorman et al, 1992, Morgan \& Hunt, 1994, Naude \& Buttle, 2000, Wilson, 1995), co-operative, co-ordinating and collaborative $\left(C^{3}\right.$ behaviour) (Axelrod, 1984, Humphries \& Wilding, 2001c, Oliver, 1990, Stern \& Reve, 1980), long-term orientation (Oliver, 1990), power (Ganesan, 1994, Gundlach, 1993, Gummesson, 1999, Hatch, 1997, Tuten \& Urban, 2001), adaption (Metcalf et al, 1992), interdependence (Lewin \& Johnston, 1997, Mohr \& Spekman, 1994) and communication (Morgan \& Hunt, 1994, Moss Kanter, 1994, Tuten \& Urban, 2001).

However, the literature reviewed concentrates on commercial companies within 'normal' markets and provides little insight into monopolistic UK DP relationships (Humphries \& Wilding, 2001c).

\section{$\underline{\text { Relationships within TCE }}$}

TCE draws upon Law, Economics and Organisation theory as base disciplines and thinking has been dominated by Oliver Williamson's seminal ideas in the field (Gundlach \& Murphy, 1993, Williamson, 1975, 1979, 1996). TCE concentrates on the need to economise on the cost of transactions including negotiating and enforcing contracts and internal control and management overheads (Faulkner \& De Rond, 2000, Palmer, 2001). Individuals are 'economic actors' and theories focus on adopting appropriate forms of governance to minimise the risks associated with opportunistic behaviour (Hill, 1980 2000, Macneil, 1980, Madhok, 2000, Nooteboom, 1999). Relationship-building includes investments in specific assets (un-recoverables such as time and resources) which generate mutual dependence and serve as hostages against opportunism. Williamson (1996) believed that a farsighted, 'calculative' approach to commercial contracting was required that relied on cost- 
effective contractual safeguards rather than trust. Although TCE is not a dynamic theory (Besanko et al, 2000), it ignores the relational aspects of co-operation such as trust which evolve over time and change the nature of the transactions themselves (Faulkner \& De Rond, 2000, Nooteboom, 1999) and, academics have moved away in the last 10 years as part of a general trend away from transactional business dealings, TCE continues to provide valid theories on why firms make or buy (Pessali \& Fernandez, 1999). However, because of the difficulties of modeling such fundamental aspects of economic exchange there is scant empirical research that integrates TCE concepts (Ghoshal \& Moran, 1996, Palmer, 2001) and especially in the UK DP business sector (Parker \& Hartley, 1997).

In trying to understand the exchange motivations within UK DP using TCE theory it is possible to explain small numbers/monopoly markets (Fishwick, 1993) using the Organisation Failure Framework in Figure 2 (Williamson, 1975) but only so far as they represent short-term, unnatural phenomena or governance choices within public utilities (Palmer, 2001, Williamson, 1996). In the stable monopoly situation which prevails in UK DP, it appears that contrary to the view that extremes of market conditions will inevitably result in pressures to escape (Hirschman, 1970, Parker \& Hartley, 1997, Williamson, 1975), the result is an impasse where neither side has the power or the motivation to improve the relationship (Parker \& Hartley, 1997). In summary, TCE theory is valid for normal markets and short-term, illegal monopolies and falls short where sustained, legal monopolies are concerned.

\section{The Research Project}

The development of SCM, RM and TCE theories appear to have mirrored the approach of the UK MoD and its industrial suppliers such that both see the need for strategic interaction at a relational rather than a transactional level (CM 4446, 1999). Moreover, they understand they must put aside their traditional approach based upon the 'power game' (Kumar, 1996) and embrace partnering principles base upon trust (Watson, 1999). However, implementing these concepts appears to be extremely difficult, potentially because of the monopolistic aspects of their situation. The literature describes a complex suite of business and relationship variables that might provides some clear insights to the improvement of monopolistic relationships within UK DP as long as one is wary of those aspects based upon assumptions of free market choice. These are illustrated in Figure 3 where we have juxtaposed a selection of business relationship 'antidotes' to the essentially negative factors in Figure 2. Given the traditionally unsuccessful nature of UK DP relationships, we adopted the positive versions of the 
following 5 dimensions as a device to pre-dispose the research subjects to consider their situation from a more objective perspective:

- $\quad$ Bounded Rationality - relationship development enabling joint creativity.

- Uncertainty/Complexity - relationship stability creating a framework for success.

- Information Impactedness - communication creating an environment for business.

- $\quad$ Opportunism - relationship reliability creating an effective business arrangement.

- $\quad$ Small Numbers - relationship quality creating the incentive to work together.

\section{Stability}

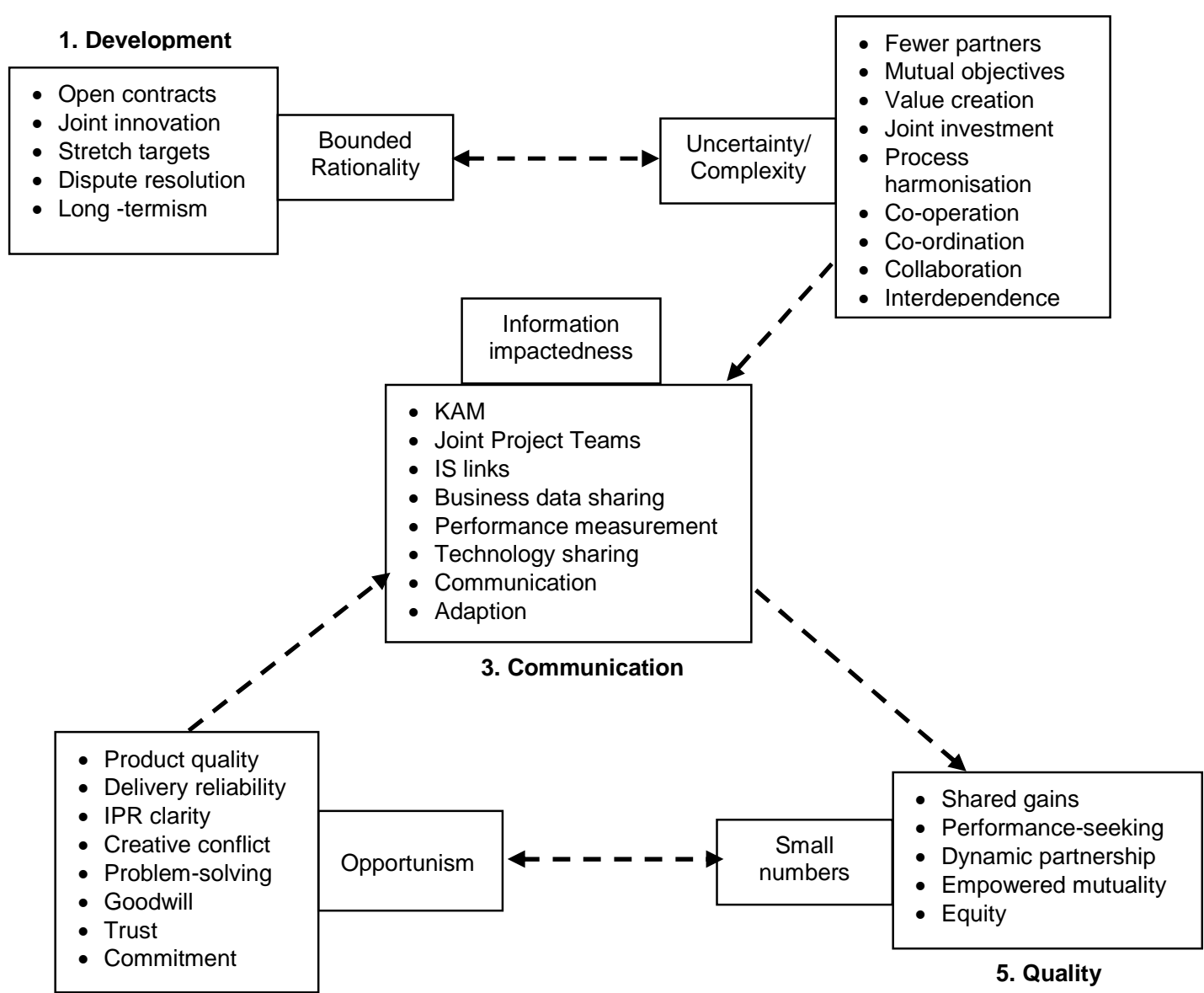

\section{Reliability}

Figure 3. A Conceptual Framework for Research - utilizing Williamson's (1975) Economic Failure Framework with Relationship Success Factors

which form a testable, theoretical framework to use as a basis of an exploratory research strategy to determine if it is possible to obtain an understanding of the monopolistic relationships within UK DP using the theoretical lens of Williamson's (1975) Organisation Failure Framework and descriptors from SCM, RM and TCE relational and behavioural factors. 
A triangulated data capture approach was designed using both quantitative (questionnaire) and qualitative (semistructured interview) methods, which aimed to measure perceptions from both relationship sides (Ganesan, 1994, Jick, 1979). Operationalisation of the research instrument concentrated on the 5 dimensions of the theoretical model in Figure 3 using a 5 point Likert scale (Youngman, 1984) with questions grounded in the literature. The dimensions and 37 questions which achieved a satisfactory 0.7977 level of Coefficient Alpha in the study (Bowman \& Ambrosini, 1997) are shown in Appendix 1. The semi-structured interview design involved following-up the dominant quantitative results by capturing 'why' information from senior managers for each dimension of the relationship in question i.e. what were the key factors that resulted in success or failure? By this additional means it was intended to obtain the richness of perceptions needed to gain insight into the subtleties and cultural depth of the business problem. Time and resource constraints limited the data capture programme to a self-selected census of 54 monopolistic relationships representing $£ 575.8 \mathrm{~m}$ annual spend (approximately one quarter of the total) within the Sea, Land and Air business units within the Defence Logistic Organisation. A total of 629 valid questionnaires were returned and 700 key points were recorded from 112 interviews. Due to the MoD status of the $1^{\text {st }}$ author, careful attention was paid to ensure that an independent stance was maintained and strict impartiality and confidentiality in the handling of data was exercised.

\section{Conclusions from the Statistical Results}

The high level, quantitative results shown in Figure 4 (the averaged questionnaire satisfaction scores per dimension) revealed that contrary to expectations the essentially negative theoretical Organisation Failure Framework, there was an overall success rating of $57 \%$.

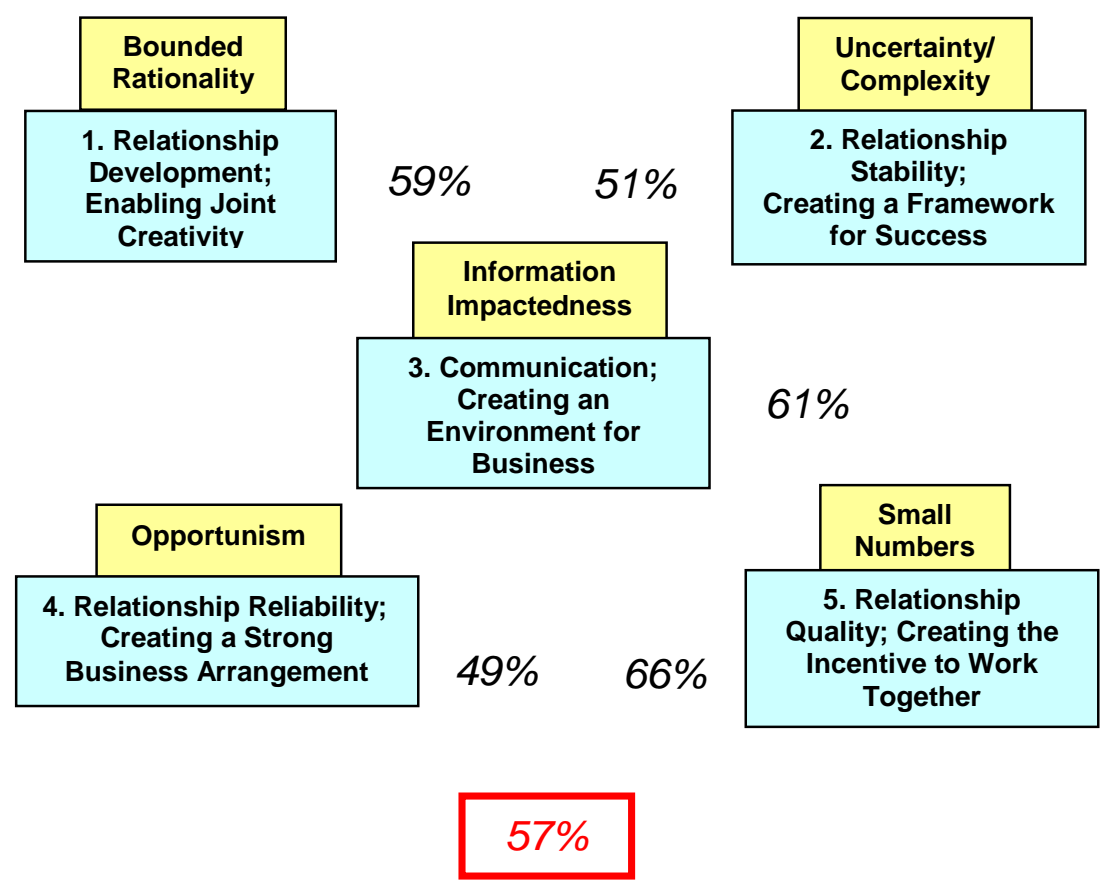

Figure 4. Overall Conceptual Framework Results by Dimension 
Only one dimension - opportunism (49\%) - was negative. The other dimensions - bounded rationality (59\%), uncertainty/complexity $(51 \%)$, information impactedness $(61 \%)$ and small numbers $(66 \%)$ - were positive. This pattern of results broken down by business unit shown in Figure 5 was reflected in $77.7 \%$ of the relationships surveyed and thus indicates a common set of characteristics across the researched UK DP business relationships.

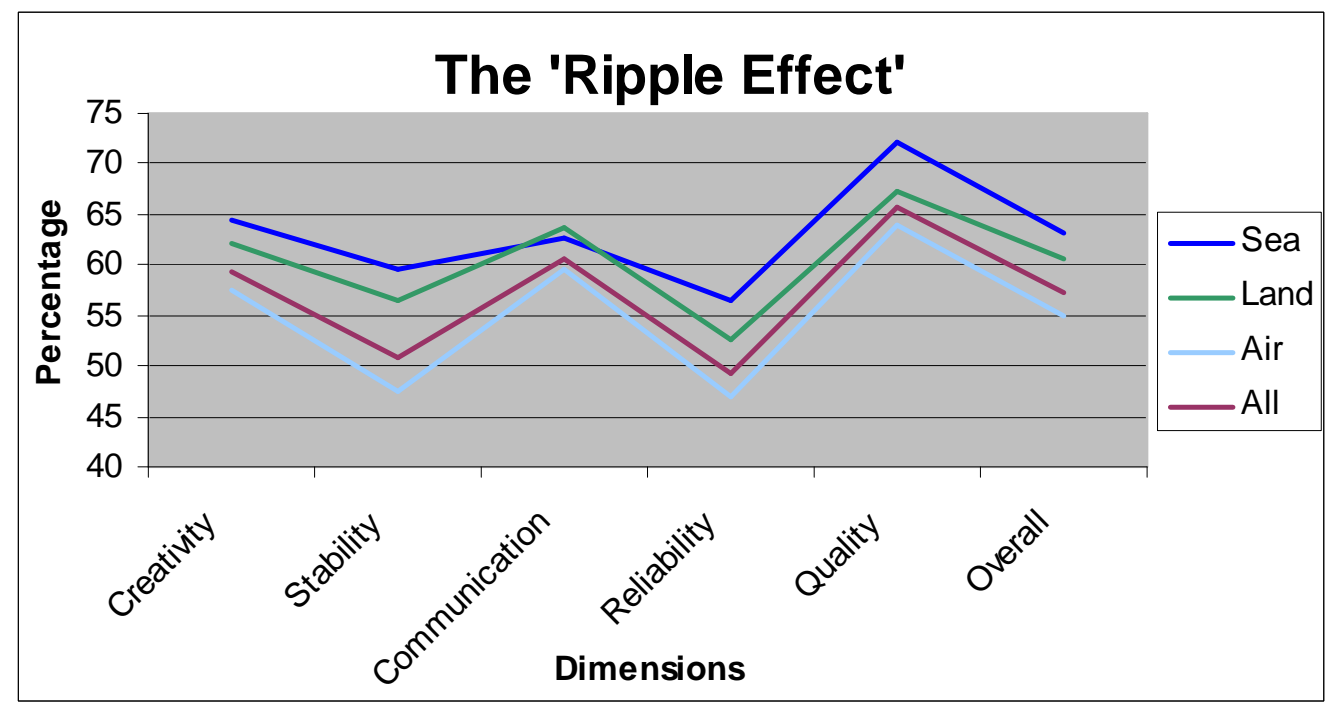

Figure 5. Comparison of Overall Business Unit Result Patterns.

It can thus be concluded that within the selected business environment overall, positive features from the selected theoretical fields outweighed the negative aspects and a predictive pattern of results was evident. Nevertheless, the negative aspects could clearly be seen to emanate from the monopoly environment. The results of overlaying the statistical data with the qualitative data (interview key points) are described next together with the consequential theoretical deductions.

\section{Implications for Supply Chain Management Theory}

The research results found that generally, despite the forced partnership monopolistic situation, the process efficiency aims of SCM were prevalent. But, although considerable efforts were being devoted to improving SCM performance, in concert with Spekman et al's (1998) commercial sector findings, successfully implemented examples were few. Moreover, difficulties in achieving effective SCM implementation could be traced to the normal, commercial difficulties surrounding order book performance, joint objectives and service level systems (Anscombe \& Kearney, 1994, Boddy et al, 2000, Braithwaite, 1998, Humphries \& Wilding, 2001c, Lamming, 1993, Spekman et al, 1998,Tompkins, 2000).

However, negative behaviour symptomatic of the theoretical monopoly environment was also clearly discernible. This included deliberate withholding of supply chain information, insular, non-integrative 
practices, commercial opportunism, unrealistic performance expectations and unco-operative product strategies. It was strongly evident that endemic DP environmental factors such as old, unreliable products, obsolescence, staff and organisational upheavals, poor end-customer visibility and lack of investment in modern procedures and systems accentuated managers' frustrations due to the lack of freedom of action available within the monopoly. These frustrations then promoted the negative behaviours implied by the theoretical framework. This situation can be illustrated in Figure 6 when Lambert et al's (1996) Partnering process model is speculatively modified to provide a monopolistic perspective.

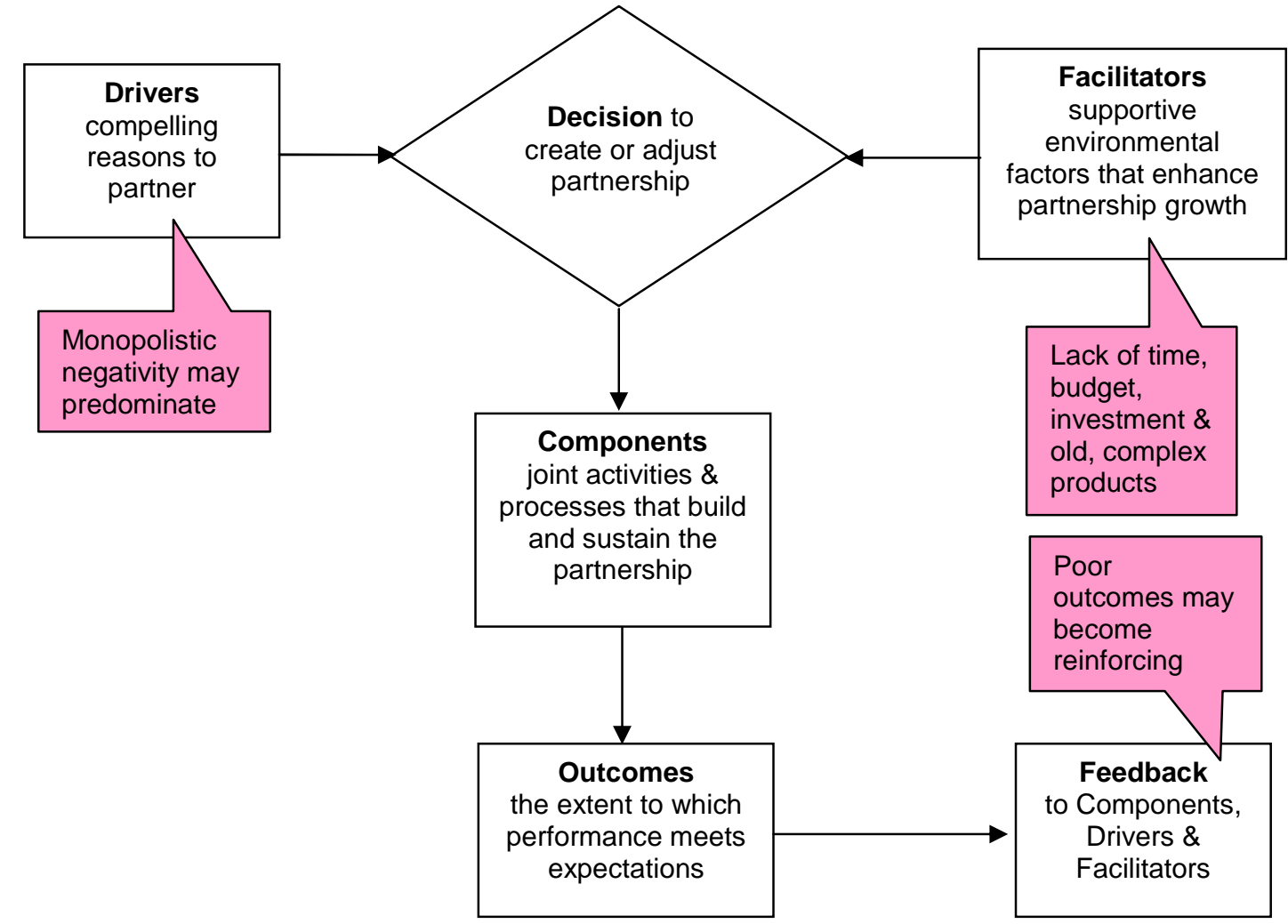

Figure 6. The Monopolistic Partnering Process (Adapted with kind permission of The International Logistics Research Institute, Copyright (2002), from Lambert et al, 1996)

Under the monopolistic situation the partners have no choice in the arrangement and depending on the degree of negativity affecting the Drivers and Facilitators, will through the Feedback loop, potentially generate a selfreinforcing, low quality relationship. We thus conclude that the use of Williamson's (1975) Organisation Failure Framework as a model when matched to SCM relational concepts has enabled new insights into sustained monopolistic business relationships to be revealed. 


\section{Implications for Relationship Marketing Theory}

The research results found that in the businesses surveyed discrete market transactions had generally been displaced by closer, long-term, strategic relationships through purposeful co-operation, shared compatible goals and seeking mutual benefit (Dyer \& Chu, 2000, McDonald et al, 1997, Mohr \& Spekman, 1994). Furthermore, efforts had been made to forge improved relationships of a dyadic nature (Anderson et al, 1994, Dwyer et al, 1987, Metcalf et al, 1992, Tuten \& Urben, 2001). But, it was found that the lack of network dynamics due to the monopoly environment had often reduced the effectiveness of attempts to discover 'common ground' on which to establish 'embeddedness' and provided a lack of incentive to dispel adversarial practices (Humphries \& Wilding, 2001c). The Marriage Analogy (Gudlach \& Murphy, 1993, Gummeson, 1999) has been dismissed as imprecise and misleading but, in the UK DP forced dyadic relationships, a much stronger case seems possible for its relevance although a key limitation is the impossibility of 'divorce'. The use of key accounts managers (McDonald et al, 1997) was almost universal although their success was dependent on personal and cultural factors.

The overwhelming majority of respondents placed strong emphasis on personal relationships ('hitting it off') and culture-matching ('relating to the way the other side do things') on the growth of trust (Gulati, 1995, Moorman et al, 1992, Moss Kanter, 1994, Palmer, 2001). This counters the enlightened, self-interest approach (Faulkner, 2000, Goleman, 1998, Kumar, 1996, Wilson, 1995). The central importance of commitment and trust to the stability and productiveness of DP business-to-business relationships (Faulkner \& de Rond, 2000, Frow, 2001, Morgan and Hunt, 1994, Sheth \& Sharma, 1997) was also underlined. Excellent, long-term commercial arrangements, frequent, interactive, productive communications, and constructive conflict that supported repeated cycles of exchange, risk-taking and successful fulfilment of expectations were observed. These appeared to strengthen the willingness of parties to rely upon each other (Eisenhardt et al, 1997, Goleman, 1998, Lewin \& Johnston, 1997, Oliver, 1990, Palmer, 2001). However, opportunistic behaviour such as adversarial bidding, inflexible and unduly bureaucratic commercial practices, unwillingness to share proprietary data and uncaring use of power which clearly undermined both trust and commitment were also detected. $\mathrm{C}^{3}$ Behaviour, adaption and interdependence were particularly important components in relationshipbuilding investment (Doney \& Cannon, 1997, Madhok, 2000, Moorman et al, 1992, Rugman \& D’Cruz, 2000, Sheth \& Sharma, Stern \& Reve, 1980, 1997, Wilson, 1995) but their effectiveness reduced when the sincerity of the other party's intentions was doubted. Finally, environmental factors such as lack of long-term, stable 
funding for projects and investment in efficient business systems seemed to exacerbate manager's negative reactions to a lack of freedom to manoeuvre within their monopolistic situation.

An illustration that summarises the potential impact of monopoly on trust and commitment is posed in a modified Morgan and Hunts (1994) Commitment-Trust Theory shown in Figure 7.

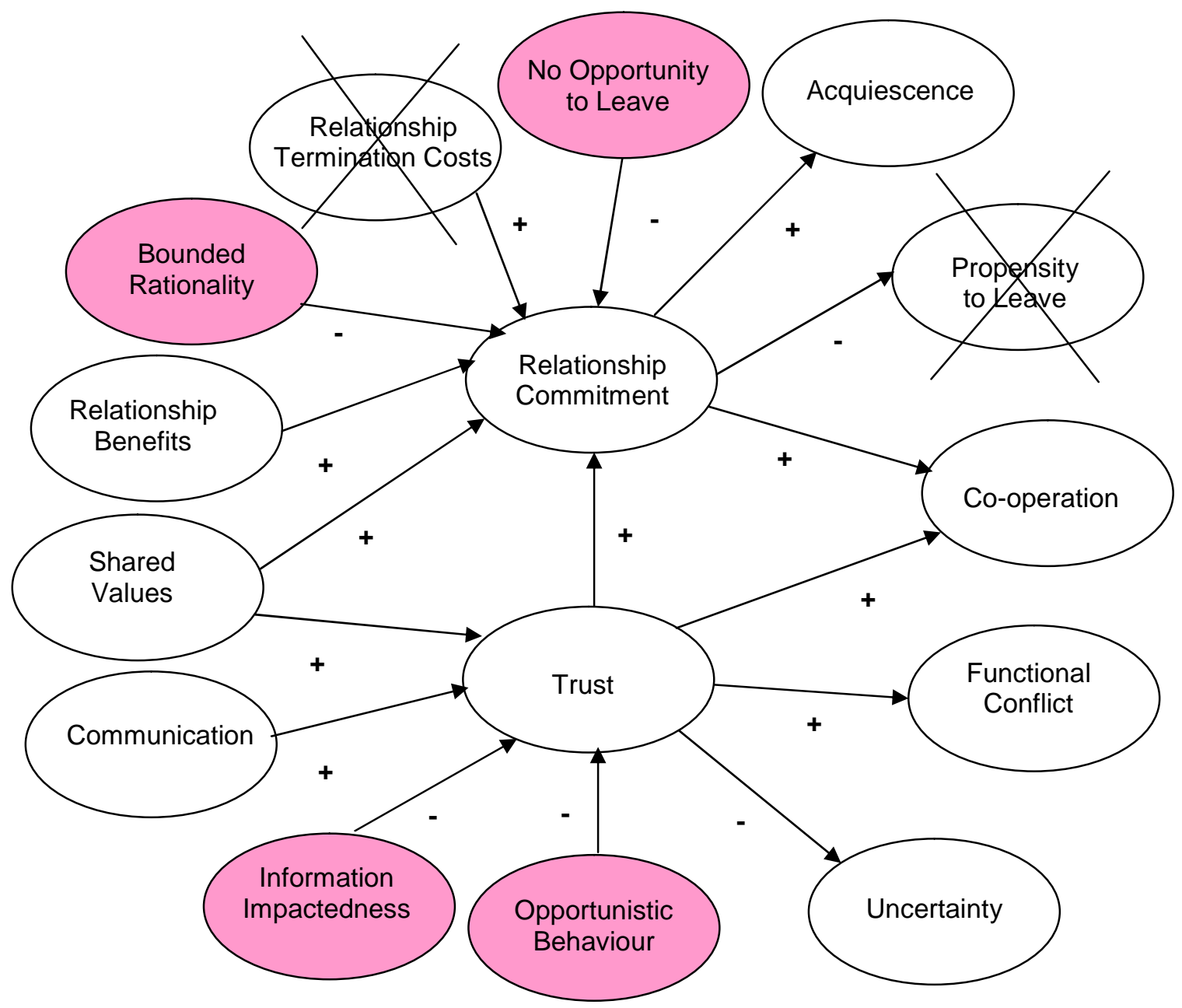

Figure 7. The Commitment-Trust Theory with Possible Monopoly Components (Adapted with kind permission of American Marketing Assoc, Copyright (2002), from Morgan \& Hunt, 1994)

The addition of these negative factors, where it is impossible for the supplier to disengage, might make the attainment of the model's positive outcomes rather more difficult to achieve and they illustrate the greater range of positive and negative inputs that potentially affect monopolistic business relationships.

\section{Implications for Transaction Cost Economics Theory}

Within UK DP it is possible to envisage the situation in Figure 8 below where both parties become locked in a 'deadly embrace', where economic power is lacking, where destructive 'competition' prevents the realisation of benefits and from which there is no escape. 


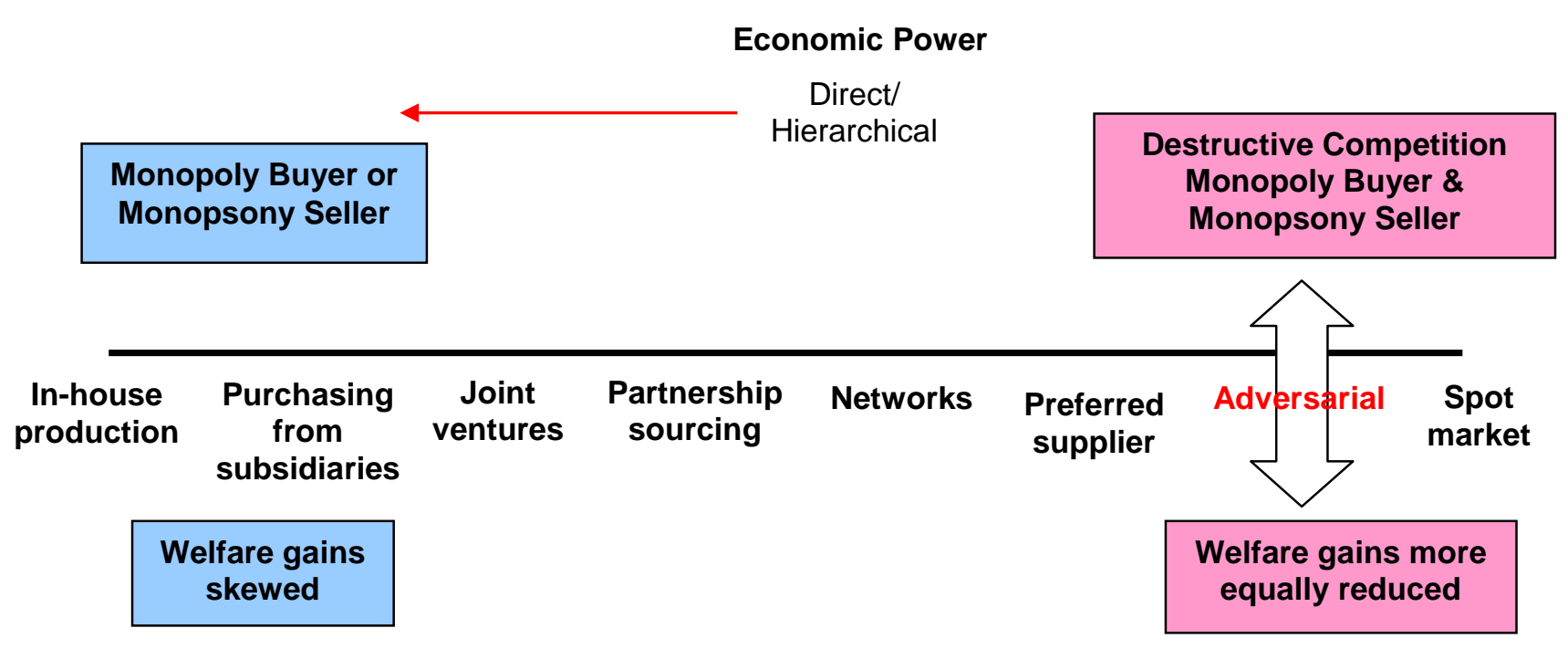

Figure 8. The Procurement Continuum - Monopoly Buyer \& Monopsony Seller (Adapted with kind permission of Elsevier Science, Copyright (2002), from Parker \& Hartley, 1997)

However, when considering the research findings dimension by dimension from Figure 4 it is evident that although negative aspects of Williamson's (1975) Organisation Failure Framework were observed, almost equally converse factors were present.

- Bounded Rationality (59\%). Examples of bounded rationality (Simon, 1957) concerning a lack of determination to set and observe mutually agreed performance standards and unwillingness to invest in specific relationship-building assets such as joint objective-setting and teamworking were observed (Ganesan, 1994). Nevertheless, creative approaches such as open contracts, joint innovation, ensuring disputes were resolved quickly and fairly and taking a long-term view of the relationship were also detected (Beamish \& Banks, 1987, Cooper \& Ellram, 1993, Van de Ven \& Walker, 1984).

- Uncertainty/Complexity (51\%). Opportunistic, short-termist behaviour such as confusing cheapest for value for money (Humphries \& Wilding, 2001a, Liston-Heyes, 1985) and lack of relationship-developing actions such as joint objective setting were observed. These reduced relationship stability and the creation of a framework for successful business (Peck et al, 2000). The highly idiosyncratic nature of the business, an imbalance in power positions and reduced interdependence because of few credible commitments were also noted (Cooper et al, 1997, Madhok, 2000). On the other hand, the need for clear, joint objectives and co-operation as a means of achieving interdependence and a reduction of costly governance measures were recognised by both sides (Beamish \& Banks, 1987, Faulkner \& De Rond, 2000, Moss Kanter, 1994, Spekman et al, 1998). 
- Information Impactedness (61\%). Problems of disclosure and implied power balance over proprietary information were detected (Sheth \& Sharma, 1997). Additionally, reticence over joint performance measurement and a lack of contract fulfilment arrangements were marked by a calculative approach to trust (Hill, 1980, Matthyssens, 1994). Nevertheless, free, frequent information sharing and the investment in specific resources such as shared data environments were evident (Faulkner \& De Rond, 2000, Harrison, 1990, Mohr \& Spekman, 1994, Morgan \& Hunt, 1994).

- Opportunism (49\%). Information impactedness resulting from selective and deliberate withholding of highly specific, proprietary and supply chain data as well as opportunism resulting in poor service delivery (Christopher, 1997, Harrison, 1990) and unsatisfactory commercial practices were found under this dimension (Hill, 1990, Noordewier et al, 1990). Buyers especially accused sellers of abusing their monopoly position and behaving opportunistically by failing to display goodwill, trust and commitment (Beamish \& Banks, 1987, Faulkner \& De Rond, 2000, Palmer, 2001, Williamson, 1979) to provide an adequate service. Conversely, interdependence achieved through the credible commitment of specific, relationship-building assets such as stable work force and product/process development and, joint problemsolving arrangements appeared to strengthen relationships by creating a more reliable business infrastructure (Argyres \& Porter Liebskind, 1999, Doz \& Baburoglu, 2000, Goleman, 1998, Hatch, 1997, Hulme, 1997).

- Small Numbers (66\%). The failure of contractual governance to maintain equity (Watson, 1999, Zajac \& Olsen, 1993) and relationships free of fear of 'imprisonment' (Eisenhardt et al, 1997, Kramer, 1999) indicated that archetypal negative relationship features from Williamson's (1975) framework are eminently possible in real life. However, many instances of long-termism and interdependence marked by cooperation and investments in relationship-promoting resources were also in evidence (Cooper \& Gardner, 1993). Moreover, respondents realised the difficulties inherent in the business and the monopoly situation and were actively striving to turn round the unsatisfactory position because they felt that 'some win' was better than 'all lose' (Axelrod, 1984, Granovetter, 1985, Ouchi, 1980). This was contrary to the view that within the failed market there is little incentive to co-operate, control costs or improve output quality (Hirschman, 1970, Williamson, 1996).

\section{Theory Conclusions and Overall Contribution to Knowledge}

The SCM, RM and TCE fields provide a useful basis for understanding business-to-business relationships. They all describe a trend away from transactional to relational business dealings but explanations fall short 
where sustained monopolies are concerned. Because of the difficulties of modelling such fundamental aspects of economic exchange there is scant empirical research that integrates TCE concepts (Ghoshal \& Moran, 1996, Palmer, 2001) and especially in the UK DP business sector (Parker \& Hartley, 1997). Moreover, this research rarely covers both buyer and supplier perspectives (Ghoshal \& Moran, 1996). This exploratory research, which appears to be the only empirical study on a significant sample of stable monopoly relationships, has thus extended these boundaries. The main finding is that contrary to expectations, a surprising diversity of positive, business-driven behaviours was present within the monopolistic UK DP environment as well as more adverse monopolistic dynamics. As predicted by the model, lack of investment in specific assets such as work force stability and product/process development, the use of inadequate performance measures, opportunistically providing poor goods and services and, using proprietary information as a weapon, reduced the chances of achieving interdependence and equitable outcomes. On the other hand despite the adverse monopolistic influences, strong counterbalancing, positive business drivers were able to produce examples of relationshipbuilding, specific investments, co-operative behaviour, open communications and a desire to reduce the burden of governance through more equitable, long-term arrangements.

The research findings suggest a different view of the adopted theoretical framework in Figure 3. Figure 9 summarises this position. At either end of the transactional/relational spectrum there are positive and negative attracting influences, which drive behavioral results that influence the relationships.

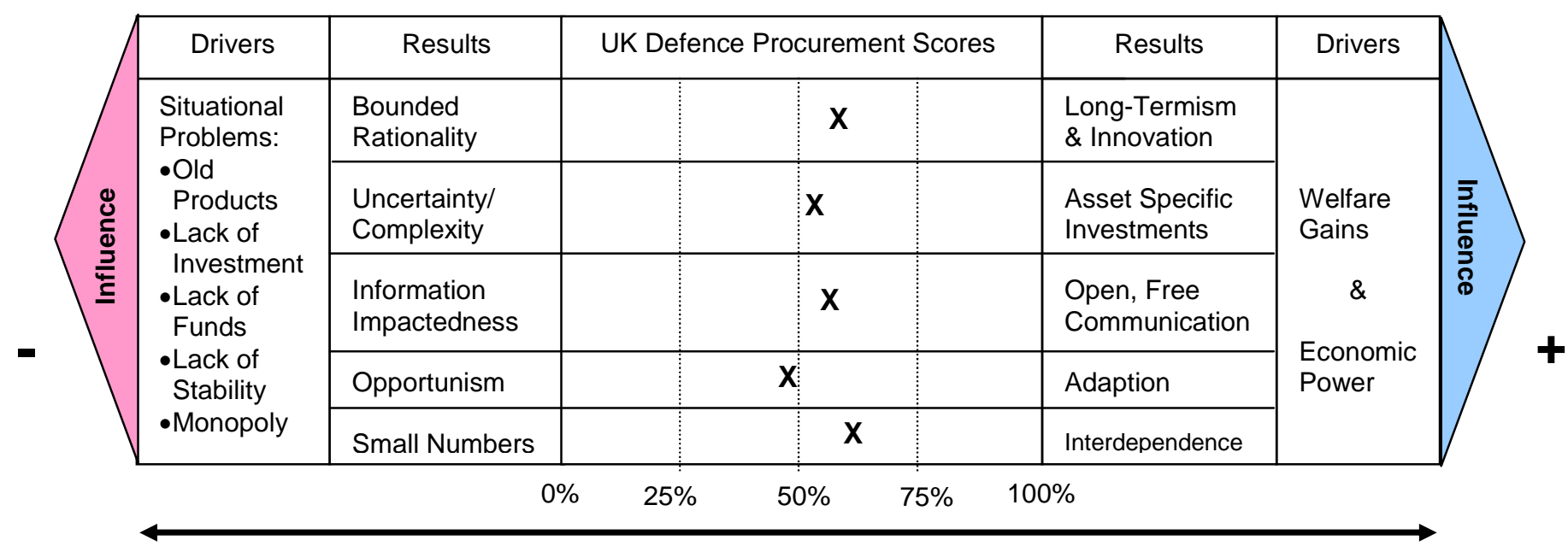

Figure 9. UK DP Monopolistic Relationship Influences. 
The research quantitative findings have been superimposed on this model to illustrate its use and demonstrate the knowledge contribution of this research. In effect it reveals a very interesting and complex set of business relational dynamics and opens up the possibility of many interesting opportunities for further research. Finally, the interdisciplinarity approach to this research using 3 disciplines has produced transcendent insights that would not be perceived by the individual disciplines working alone (Starkey \& Madan, 2001).

\section{Implications for Managers}

Within UK DP the pattern of results indicates that manager need to accept that the monopoly environment will inevitably reduce relationship quality and examining relationships from both sides, using this information in an open, constructive manner will facilitate understanding and therefore improvement. However, reducing the impact of environmental influences that, due to the limited availability of options for action, cause frustration will also limit negative behaviours. The research results indicate that paying particular attention to synchronising objectives and confidence-building as well as service and product delivery, lowering joint costs and risks and measures to support the growth of trust. Finally, the research approach clearly suggests the benefit to taking a strategic approach to measuring the quality of business-to-business relationships so that the best and worst can be identified and why and targeted action can be taken and progress may be tracked (Humphries \& Wilding, 2001b).

\section{$\underline{\text { Limitations }}$}

This research has used a narrow view through a specific theoretical model lens to achieve a specified understanding of monopolistic UK DP business relationships and necessarily; the approach has been high level due to the exploratory nature of the research. It is thus essential to view the value of the research only through this very narrow gap and to accept that other models and research designs will be need to be used in order to triangulate its findings and assess its wider generalisability.

\section{Implications for Further Research}

This research has been limited in its scope and depth due to time and resources. It has nevertheless, for the first time achieved a cross-relationship (MoD/Industry) perspective of a significant sample of sustained monopoly businesses. This 'cracking open the door' suggests that further research would be interesting to academics and useful to the increasingly globalised DP business as well as other business areas with monopolistic characteristics. The subject area could potentially offer rich opportunities for longitudinal studies, proactive approaches such as action and experimental research as well as the use of alternative theoretical fields. We also 
recommend that that none should be viewed in isolation since many overlap and converge and, provide the chance to carry out integrated research programmes.

\section{A Final Word}

The literature suggests that the little known about the relationship dynamics within monopolies presupposes negative outcomes. This research has shown that although behavioural characteristics can be recognised in the literature, a spectrum of positive and negative results were exposed and the main dynamics could be understood. The contribution to knowledge plus the inherent limitations of the study have suggested an agenda for future research which it is hoped will advance the SCM, RM and TCE fields and provide greater perspectives into the workings of monopolistic business-to-business relationships. 


\section{Appendix 1 - Questionnaire Dimensions and Questions}

1. Creativity: promoting quality, innovation and long-term approach by encouraging high performance.

a. The relationship encourages the achievement of high performance by both parties ie. reliable equipment, on-time delivery, good forecasts.

b. The relationship encourages us to be innovative in the way we do business.

c. Performance measurement is used to raise standards.

d. Disputes \& problems are resolved: 'quickly'.

e. Disputes \& problems are resolved: 'fairly'.

f. The other party is reliable and consistent in dealing with us.

g. The other party is dedicated to making our business a success.

h. When an unexpected problem arises, both parties would rather work out a solution than hold each other to the original contract terms.

2. Stability: synchronisation of objectives and confidence building.

a. The other party displays a sound, strategic understanding of our business.

b. The objectives of both parties are clearly stated.

c. The objectives of both parties are fully compatible.

d. Both parties co-operate wholeheartedly.

e. The relationship provides a dynamic business environment within which both parties can seek increasing rewards.

f. I have complete confidence in the intentions of the other party.

3. Communication: shared data environment, openness, common performance measures, frequent interaction.

a. Where the other party has proprietary information that could improve the performance of the joint business, it is freely available.

b. We would welcome a shared data environment where planning, technical and pricing information are made freely available.

c. We understand the information requirements of all participants in the support chain from sub-contractors to end-user.

d. Exchange of information in this relationship takes place frequently and informally - not just according to specified agreement.

e. Objective performance measurement is an important part of this relationship.

f. We are aware of the performance requirements for all participants in the support chain from subcontractors to end-user.

g. We provide the other party with regular information including long-range forecasts to enable him to do his business better.

$4 \quad$ Reliability: concentrating on service and product delivery, lowering joint costs and risks, building up trust.

a. The quality of the contract outputs ie. spares/repairs/services, is entirely satisfactory.

b. The quality of service delivery ie. delivery times, billing, payment, is entirely satisfactory.

c. The relationship is characterised by a continually improving quality ethos.

d. Problems are solved in a joint, open, constructive manner.

e. Such is the goodwill in the relationship, the other party would willingly put himself out to adapt to our changing requirements.

f. We trust the other party to act in our best interests.

g. The responsibility for making sure the relationship works is shared jointly.

h. The other party provides us with useful cost reduction and quality improvement ideas.

i. The other party is always totally open and honest with us.

j. The other party always does what he says he will do.

5. Quality: creating a win-win relationship in which each side is delighted to be a part.

a. The gains from this relationship are equally shared between both parties. 
b. We do not feel imprisoned within the current relationship.

c. We are willing to invest more ie. money, time, information, effort, in the current relationship.

d. We are happy that our future is bound to the success of our relationship partner.

e. We feel totally committed to this relationship.

f. The other party is genuinely concerned that our business succeeds.

g. Both sides are working to improve this relationship.

Scoring:

Strongly agree -4

Tend to agree -3

Tend to disagree -2

Strongly disagree -1

Insufficient knowledge - 0 


\section{References}

Anderson, JC, Håkansson, H, and Johanson, J. (1994) Dyadic Business Relationships within a Business Network Context. Journal of Marketing 58(Oct), pp. 1-15.

Anscombe, J and Kearney, A T. (1994) Partnership or Power Play? Logistics Focus 2(6)

Argyres, NS and Porter Liebskind, J. (1999) Contractual Commitments and Governance Inseperability: Incorporating History into Transaction Cost Theory. Academy of Management Review 24(1), pp. 49-63.

Axelrod, R. (1984) The Evolution of Co-operation. Penguin Books, In: The Challenge of the Political Environment, MBA B885, pp. 8-9. The Open University, Milton Keynes, 1995.

Beamish, PW and Banks, JC. (1987) Equity Joint Ventures and the Theory of the Multinational Enterprise. Journal of International Business Studies (Summer), pp. 1-16.

Bechtel, C and Jayaram, J. (1997) Supply Chain Management: A Strategic Perspective. The International Journal of Logistics Management 8(1), pp. 15-34.

Besanko, D, Dranove, D, and Shanley, M. (2000) Economics of Strategy, ch. 2. Second Edition. Wiley \& Sons Inc, USA.

Boddy, D, Macbeth, D, and Wagner, B. (2000) Implementing Cooperative Strategy: A Model from the Private Sector. In: David O Faulkner and Mark de Rond (Eds) . Cooperative Strategy: Economic, Business and Organisational Issues, Oxford University Press, New York, p. 195.

Bowman, C and Ambrosini, V. (1997) Using Single Respondents in Strategy Research. British Journal of Management 8, pp. 119-131.

Braithwaite, A. (1998) The Nine Maxims of Supply Chain Management. Proceedings of the Logistics Research Network Conference 10/11 Sep 98 Cranfield.

Christopher, M. (1997) Marketing Logistics, pp. 29-79. Butterworth-Heinemann, Oxford.

Cm 4446. (1999) The Defence White Paper. Directorate of Policy Planning, The Stationery Office.

Cooper, MC and Ellram, LM. (1993) Characteristics of Supply Chain Management \& the Implications for Purchasing \& Logistics Strategy. The International Journal of Logistics Management 4(2), pp.13-24

Cooper, MC, Ellram, LM, Gardner, JT, and Hanks, AM. (1997) Meshing Multiple Alliances. Journal of Business Logistics 18(1), pp. 67-89.

Cooper, MC and Gardner, JT. (1993) Building Good Relationships - More than Just Partnering or Strategic Alliances? International Journal of Physical Distribution \& Logistics Management 23(6), pp. 14-26

Cox, A. (2000) The Power Perspective in Procurement and Supply Management. Journal of Supply Chain Management (Spring). pp. 4-7.

DASA. (2001) UK Defence Statistics 2001, Table 1.5. MoD/HMSO, Norwich.

Doney, PM and Cannon, JP. (1997) An Examination of the Nature of Trust in Buyer-Seller Relationships. Journal of Marketing 61(Apr), pp. 35-51.

Doz, YL and Baburoglu, O. (2000) From Competition to Collaboration: The Emergence and Evolution of R\&D Cooperatives. In: David O Faulkner and Mark de Rond (Eds). Cooperative Strategy: Economic, Business and Organisational Issues, pp. 176-188. Oxford University Press, New York.

Dwyer, RF, Schurr, PH, and Oh, S. (1987) Developing Buyer-Seller Relationships. Journal of Marketing 51(Apr), pp. 11-17. 
Dyer, JH and Chu, W. (2000) The Determinants of Trust in Supplier-Automaker Relationships in the USA, Japan and Korea. Journal of International Business Studies 31(2), pp. 259-285.

Eisenhardt, KM, Kahwajy, J, and Bourgeoise, L J. III. (1997) How Management Teams Can Have a Good Fight. Harvard Business Review (Jul-Aug), pp. 77-85.

Ellram, LM and Edis, ORV. (1996) A Case Study of Successful Partnering Implementation. International Journal of Purchasing \& Materials Management (Sep), pp. 20-38.

Evans, JR and Berman, B. (2001) Conceptualizing and Operationalizing the Business-to-Business Value Chain. Industrial Marketing Management 30, pp. 135-148.

Faulkner, DO. (2000) Trust and Control: Opposing or Complementary Functions? In: David O Faulkner and Mark de Rond (Eds). Cooperative Strategy: Economic, Business and Organisational Issues, p. 341. Oxford University Press, New York.

Faulkner, DO and de Rond, M. (2000) Cooperative Strategy: Economic, Business and Organizational Issues, pp. 7-32 Oxford University Press, New York.

Fishwick, F. (1993) Making Sense of Competition Policy, pp. 27-70. Kogan Page, London.

Frow, P. (2001) Commitment in Professional Service Relationships: Issues Relating to the Meaning of Commitment. World Marketing Congress Eds: Spotts, Holman E, Meadow, H Lee, and Smith, Scott M. Global Marketing Issues at the Turn of the Millenium.

Ganesan, S. (1994) Determinants of Long-Term Orientation in Buyer-Seller Relationships. Journal of Marketing 58(Apr), pp. 1-19.

Ghoshal, S and Moran, P. (1996) Bad for Practice: A Critique of the Transaction Cost Theory. Academy of Management Review 21(1), pp. 13-47.

Goleman, D. (1998) Working with Emotional Intelligence. pp. 227-228. Bloomsbury Publishing Plc, London.

Granovetter, M. (1985) Economic Action and Social Structure: The Problem of Embeddedness. American Journal of Sociology 91(3 (Nov)), pp. 481-510.

Grant, RM. (1995) Contempory Strategy Analysis, pp. 249-250 Blackwell, Oxford.

Gulati, R. (1995) Does Familiarity Breed Trust? The Implications of Repeated Ties for Contractual Choice in Alliances. Academy of Management Journal 38(1), pp. 85-112.

Gummerson, E. (1999) Total Relationship Marketing, pp. 75-79 Butterworth Heinemann, Oxford.

Gundlach, GT and Murphy, PE. (1993) Ethical and Legal Foundations of Relational Marketing Exchanges. Journal of Marketing 57(Oct), pp. 35-46.

Harrison, Alan. (1990) Co-makership as an Extension of Quality Care. International journal of Quality \& Reliability Management 7(2), pp. 15-22.

Hartley, K. (1998) Defence Procurement in the UK. Defence \& Peace Economics 9, pp. 39-61.

Hatch, MJ. (1997) Organization Theory. pp. 282-5. Oxford University Press, Oxford.

Hill, CW L. (1990) Co-operation, Opportunism, and the Invisible Hand: Implications for Transaction Cost Theory. Academy of Management Review 15(3), pp. 500-513.

Hirschman, AO. (1970) Exit, Voice, and Loyalty, pp. 26-137. Harvard University Press, Cambridge, Mass.

Hulme, MR. (1997) Procurement Reform \& MIS Project Success. International Journal of Purchasing \& 
Materials Management 33(Winter), pp. 2-15.

Humphries, AS and Wilding, R. (2001b) Myth or Reality. Supply2Primes 1(Sep), pp 8-13.

Humphries, AS and Wilding, R. (2001a) Partnering in Defence Procurement: The Monopoly Perspective. Proceedings of the Royal Aeronautical Society Conference on: The Impact of Smart Acquisition on Repair and Maintenance, 20th February London, UK.

Humphries, AS and Wilding, R. (2000) Partnering in UK Defence Procurement: Myth or Reality? Proceedings of the Logistics Research Network 5th Annual Conference 7th \& 8th September, pp. 281-289 Cardiff University.

Humphries, AS and Wilding, R. (2001c) Partnerships in UK Defense Procurement. The International Journal of Logistics Management 12(1), pp 83-96.

Jick, TD. (1979) Mixing Qualitative and Quantitative Methods: Triangulation in Action. Administrative Science Quarterly 24, pp. 602-611.

Kakabadse, A and Kakabadse, N. (2000) Sourcing: New Face to Economies of Scale and the Emergence of New Organisational Forms. Knowledge \& Process Management 7(2), pp. 107-118.

Kramer, RM. (1999) Trust \& Distrust in Organisations: Emerging Perspectives, Enduring Questions. Annual Review of Psychology 50, pp. 569-598.

Kumar, N. (1996) The Power of Trust in Manufacturer-Retailer Relationships. Harvard Business Review (NovDec), pp. 92-105.

Lambert, DM, Emmelhainz, MA, and Gardner, John T. (1996) Developing and Implementing Supply Chain Partnerships. The International Journal of Logistics Management 7(2), pp. 1-17.

Lamming, R. (1993) Beyond Partnership: Strategies for Innovation \& Lean Supply, pp. 28-64. Prentice Hall, London.

Lewin, JE and Johnston, WJ. (1997) Relationship Marketing Theory in Practice: A Case Study. Journal of Business Research 39, pp. 23-31.

Liston-Heyes, C. (1995) Management Systems and Defence Procurement. Defence \& Peace Economics 6, pp. 111.

Macneil, IR. (1980) The New Social Contract: An Inquiry into Modern Contractual Relations, ch. 1. Yale University Press, New Haven \& London.

Madhok, A. (2000) Transaction (In) Efficiency, Value (In) Efficiency and Inter-Firm Collaboration . In: David O Faulkner and Mark de Rond (Eds) . Cooperative Strategy: Economic, Business and Organisational Issues, pp. 78-85. Oxford University Press, New York.

Matthyssens, P and Van den Bulte, C. (1994) Getting Closer and Nicer: Partnerships in the Supply Chain. Long Range Planning 27(1), pp. 72-83.

McDonald, M, Millman, AF, and Rogers, B. (1997) Key Account Management: Theory, Practice and Challenges. Journal of Marketing Management 13, pp. 737-757.

Metcalf, LE, Frear, CR, and Krishnan, R. (1992) Buyer-Seller Relationships: An Application of the IMP Interaction Model. European Journal of Marketing 26(2), pp. 27-46.

Mohr, J and Spekman, R. (1994) Characteristics of Partnership Success: Partnership Attributes, Communication Behavour, and Conflict Resolution Techniques. Strategic Management Journal 15, pp. 135-152.

Moorman, C, Zaltman, G, and Deshpande, R. (1992) Relationships Between Providers \& Users of Market 
Research: The Dynamics of Trust Within and Between Organisations. Journal of Marketing Research 29(Aug), pp. 314-328.

Morgan, RM and Hunt, SD. (1994) The Commitment-trust Theory of Relationship Marketing. Journal of Marketing 58(3), pp. 20-38.

Moss Kanter, R. (1994) Collaborative Advantage: Successful partnerships manage the relationship, not just the deal. Harvard Business Review, pp. 96-108.

Naude, P and Buttle, F. (2000) Assessing Relationship Quality. Industrial Marketing Management 29, pp. 351361.

Noordewier, TG, John, G, and Nevin, JR. (1990) Performance Outcomes of Purchasing Arrangements in Industrial Buyer-Vendor Relationships. Journal of Marketing (Oct), pp. 80-93.

Nooteboom, B. (1999) Interfirm Alliances: Analysis and Design. Routledge, pp. 45-57. London \& New York.

Oliver, C. (1990) Determinants of Interorganisational Relationships: Integration and Future Directions. Academy of Management Review 15(2), pp. 241-265.

Ouchi, WG. (1980) Markets, Bureaucracies and Clans. Administrative Science Quarterly 25, pp. 129-141.

Palmer, A. (2001) Co-operation and Collusion: Making the Distinction in Marketing Relationships. Journal of Marketing Management 17, pp 761-784.

Parker, D and Hartley, K. (1997) The Economics of Partnership Sourcing Versus Adversarial Competition: A Critique. The European Journal of Purchasing \& Supply Management 3(2), pp. 115-125.

Peck, H and Jüttner, U. (2000) Strategy and Relationships: Defining the Interface in Supply Chain Contexts. The International Journal of Logistics Management 11(2), pp. 33-44.

Pessali, HF and Fernandez, RG. (1999) Institutional Economics at the Micro Level? What Transaction Costs Theory Could Learn from Original Institutionalism (In the Spirit of Building Bridges). Journal of Economic Issues 33(2), pp. 265-275.

Porter, ME. (1980) Competitive Strategy, Ch. 1. The Free Press, New York.

Rousseau, DM, Sitkin, SB, Burt, RS, and Camerer, C. (1998) Not so different after all: A Cross-Discipline View of Trust. Academy of Management Review 23(3), pp. 393-404.

Rugman, AM and D'Cruz, JR. The Theory of the Flagship Firm in Cooperative Strategy. In: David O Faulkner and Mark de Rond (Eds). Cooperative Strategy: Economic, Business and Organisational Issues, Oxford University Press, New York, pp. 58-61.

Sheth, JN and Sharma, A. (1997) Supplier Relationships: Emerging Issues \& Challenges. Industrial Marketing Management 26, pp. 91-100.

Simon, HA. (1957) A behavioral model of rational choice. Models of Man In: Hatch, Mary Jo. Organisation Theory, p. 274 Oxford, Oxford University Press, 1997.

Spekman, RE, Kamauff, JW Jr, and Myhr, N. (1998) An Empirical Investigation into Supply Chain Management: A Perspective on Partnerships. Supply Chain Management 3(2), pp. 53-67.

Starkey, K and Madan, P. (2001) Bridging the Relevance Gap: Aligning Stakeholders in the Future of Management Research. British Journal of Management 12(Special Issue), pp S2-S26.

Stern, LW and Reve, T. ( 1980) Distribution Channels as Political Economies: A Framework for Comparative Analysis. Journal of Marketing 44(Summer), pp. 52-64. 
Stevens, GC. (1989) Integrating the Supply Chain. International Journal of Physical Distribution \& Logistics Management 19(8), pp. 3-8.

Tompkins, JA. (2000) No Boundaries: Moving Beyond Supply Chain Management, p 53, Tompkins Press, Raleigh, NC.

Tuten, TL and Urban, DJ. (2001) An Expanded Model of Business-to-Business Partnership Formation and Success. Industrial Marketing Management 30, pp. 149-164.

Van de Ven, AH and Walker, G. (1984) The Dynamics of Interorganisational Coordination. Administrative Science Quarterly 29, pp. 598-621.

Watson, K. (1999) Is Partnering Starting to Mean..: Partnering - What Does it Mean to You? Touted as a Method of Banishing Adversarial Relarionships to the Past, the Balance Sheet is Now Being Drawn Up. Contract Journal (Feb), pp. 1-7.

Webster, FE.Jr. (1992) The Changing Role of Marketing in the Corporation. Journal of Marketing 56(Oct), pp. $1-17$.

Williamson, OE. (1975) Markets \& Hierarchies: Analysis \& Anti-trust Implications, pp. 39-40. The Free Press, New York.

Williamson, OE. (1996) The Mechanisms of Governance, pp. 84, 369. Oxford University Press, Oxford.

Williamson, OE. (1979) Transaction-cost Economics: The Governance of Contractual Relations. Journal of Law \& Economics 22, pp. 233-261.

Wilson, DT. (1995) An Integrated Model of Buyer-Seller Relationships. Journal of the Academy of Marketing Science 23(4), pp. 335-345.

Youngman, MB. (1984) Designing Questionnaires. Open University, In: Bell, Judith, Bush, Tony, Fox, Alan, Goodey, Jane, and Goulding, Sandy (Eds). Conducting Small-scale Investigations in Educational Management, ch. 9. Harper \& Row, London.

Zajac, EJ and Olsen, CP. (1993) From Transaction Cost to Transactional Value Analysis: Implications for the Study of Interorganisational Strategies. Journal of Management Studies 30(1), pp.131-145. 